\title{
Race (and Gender and Class) and Child Custody: Theorizing Intersections in Two Canadian Court Cases
}

Charmaine C. Williams

\author{
Version Publisher's \\ Citation Williams, C. C. (2004). Race (and Gender and Class) and Child Custody: \\ (published version) Theorizing Intersections in Two Canadian Court Cases. NWS A \\ Journal, 16(2), 46-69. doi:10.2979/nws.2004.16.2.46
}

How to cite TSpace items

Always cite the published version, so the author(s) will receive recognition through services that track citation counts, e.g. Scopus. If you need to cite the page number of the author manuscript from TSpace because you cannot access the published version, then cite the TSpace version in addition to the published version using the permanent URI (handle) found on the record page.

This article was made openly accessible by $U$ of $T$ Faculty.

Please tell us how this access benefits you. Your story matters. 


\title{
Race (and Gender and Class) and Child Custody: Theorizing Intersections in Two Canadian Court Cases
}

\author{
CHARMAINE C. WILLIAMS
}

In the summer of 2001, the Canadian media devoted attention to two court cases that resulted in mothers losing custody of their children. Kimberly Van de Perre and Nadia Hama might have been overlooked if the presentation of their cases had not evoked discussion regarding the relevance of claims of racism in custody decisions. Analysis of the media narrative reveals that the narrow focus on race distorted perceptions of these family situations, and contributed to the marginalization of the two single mothers involved. This paper examines this process to explore how an analysis based on multiple identities, and simultaneous existence of oppression and privilege, may have led to different outcomes for these two families.

Keywords: race / intersectionality / media / child custody / single mothers

Two child custody cases attracted a great deal of media attention in Canada during the summer of 2001. Kimberly Van de Perre, the mother of a young son, lost custody of the child to her former lover. Nadia Hama, a mother of two children, lost custody of the children to her ex-husband. These two situations were newsworthy partly because they both resulted in mothers being denied custody of their children. Yet they were also remarkable because of the discourse they evoked around race and racism in Canada. There is a common perception that Canada has a benign history of race relations and is relatively untroubled by racism. This perception is reinforced through comparisons with our neighbors to the South. Juxtaposed against America's high profile history of legally sanctioned racism and eruptive racial conflict, Canada presents the image of an egalitarian, harmonious environment. However, there is a great deal of research that shows racism is equally embedded in both nations, and the true difference is that Canadians do not openly acknowledge these tensions (Henry, Tator, Mattis, and Rees 1994; Reitz and Breton 1994). Therefore, the candid discussion of race and racism in the nation's newspapers signaled a noteworthy Canadian moment. Suddenly, race and racism were part of popular discussion.

I became interested in exploring these two custody cases because my students asked if we could discuss them in a class I was teaching on multicultural social work practice. They wanted to know how we could understand or evaluate the validity of the claims of racism in both cases, and they were curious about the media discourse they were evoking in 
both Canada and the United States. The media presented the two cases to the public through the lens of a racial analysis, yet the people involved were more than agents arranged along a racial divide. They also represented differences in gender, class, nationality, and other identities. The students' attempts to grapple with these coexisting identities was reflective of a current moment in academic and social discourse when we recognize that multiple identities, and multiple oppressions, converge in the experiences of individuals and groups. This recognition has enriched our understanding of diversity, but it has also created confusion. Although we are now able to identify various types of oppression in operation, we are less skilled in engaging with the co-existence of privilege and oppression in people's lives. We need to develop analyses that can contain these two possibilities and point us toward rationales for action. This paper explores two child custody cases that presented us with this challenge.

I have based my discussion of these two cases on the news media coverage that surrounded them. The connection between media discourse and public discussion is important to this paper. It is easy to demonize the media because we are aware that news producers shape stories to titillate and entertain (Kitzinger 1996). We cannot, however, separate media representation from public opinion. The media puts forward ideas that shape what the general public thinks, but they will only be supported for reflecting what the public wants to see and believe (Ayre 2001; Neal 1998). Therefore, this analysis focuses on media narratives because the people who produce newspaper and television news stories shape and reflect public perceptions. These two custody cases marked a moment in which we could explore Canadian ideologies surrounding the role of mothers, and the relevance of race. As this analysis will reveal, the integration of race issues into these custody deliberations had powerful effects on the outcomes for these two women and their families.

\section{The Context: Child Custody and Race Relations in Canada}

Before discussing the specifics of what happened to Kimberly Van de Perre and Nadia Hama, it is necessary to describe the context in which they were forced to negotiate child custody and racialization.

Although women have conventionally borne higher responsibility for childcare, we are now witnessing an international shift of exclusive care to mothers. The United States has the highest proportion of single mothers, but this family form is quickly becoming common across industrialized nations. In all of these settings, parental separation is the most frequent precursor to single mother status. Although many assume that mothers are always favored in child custody decisions, a review of several decades of judicial decision-making in the United States has revealed 
that fathers are awarded custody 50 percent of the time. Despite this, the myth of father disadvantage has had powerful effects in recent years. Men advocating for increased access and custody of children have campaigned for recognition of the importance of fathers in the lives of children. They have also, however, bolstered their cause by generating a discourse centered on the inadequacies of mothers. Both non-custodial fathers and the courts hold women to extreme standards for parenting. Any deviation from rigid ideals of maternal suitability confers extreme disadvantage in child custody hearings, while even nominal endorsements of paternal responsibility are viewed with extreme favor. Many women for whom the courts impose joint custody arrangements are likely to find they still function as single parents, but with additional responsibilities. In Canada, increasing tendency to award access and joint custody to fathers has resulted in mothers now being held accountable for ensuring father participation. In addition, fathers not satisfied with joint arrangements have been able to use the stress of single motherhood to their advantage. Evidence of the stressors of single parenthood is often appropriated by fathers desiring to demonstrate the unsuitability of awarding custody to the mothers of their children. Therefore, men have collectively furthered a father-empowerment agenda, but they have also undermined womenled agendas seeking enforcement of child support, and other institutional recognition of women-headed family forms.

These are clearly dynamics that influenced the experience that Kimberly Van de Perre and Nadia Hama had in the courts, but they were also affected by the context of race relations in Canada. As has already been noted, there is a prevailing Canadian myth that there is no history of racism and no contemporary racial tension. However, a review of Canadian history reveals extensive reinforcement of racial hierarchies through policies and laws that controlled the activities and life opportunities of racial minority Canadians (Aylward 1999; Backhouse 1999). Canadian researchers have demonstrated that these practices continue. Canadians of non-European origin face significant discrimination in the workforce, housing market, educational systems, and other institutions (Breton, Isajiw, Kalbach, and Reitz 1990; Henry and Ginzberg 1985; Henry and Tator 1999; Henry et al. 1994). This is the outcome of colonial histories that have unfolded in Canada just as they did in the United States, but with at least one important difference. American governing bodies have developed constitutional and legal mechanisms for combating racial discrimination; this has not happened in Canada. Consequently, groups of racial minority citizens in the United States are able to advocate for legal and constitutional remedies to racism that are not available in Canada (Aylward 1999). Efforts to develop such avenues have been impeded by the development of Canadian policies that promote multiculturalism rather than addressing racism. Any attempt to discuss race relations in Canada 
is a challenge to cherished notions of Canadians as exceptionally tolerant individuals that would never perpetuate the racial injustices that seem to be prevalent in the United States. These perceptions were put to the test in these women's situations because the tensions surrounding their custody cases were positioned within discourses of racial disadvantage. As Canadians choose to maintain silence around race issues, the extent to which racism was taken up in the media discourse signaled the existence of unusual elements in these custody cases.

The discourses surrounding child custody and race relations are not conventionally joined, but they converged in the circumstances that surrounded Kimberly Van de Perre and Nadia Hama. There was something about what was happening in their families that created a moment in which it was possible to discuss things that were previously not discussed and to join these two apparently separate lines of social discourse. As the analysis will reveal, the bringing together of these issues had powerful effects on the outcomes for these two women and their families.

\section{Method}

I approached the analysis by using document analysis techniques. Document analysis involves analyzing and interpreting data generated from the examination of documents and records relevant to a particular topic (Schwandt 1997). Document analysis often includes quantitative description of document contents; however, contemporary forms have integrated interpretive analyses. I chose to follow the techniques of critical discourse analysis (Blommaert and Bulcaen 2000; Van Dijk 1993), focusing my interpretation on the links between the discourse presented in the documents, and the social setting, historical period, and structure of political relationships. This approach was essential to revealing the ways in which the discourse was implicated in shielding and reproducing patterns of domination. Authors/writers often reveal processes of domination through their representation of individuals and groups, and their construction of the context that is presented for their actions (Falzon 1998). Based on this assumption, I created a coding scheme to identify elements of the documents that were relevant to representation of the individuals involved, and characterizations of the context in which these individuals and actions were presented.

I constructed a corpus for analysis that contained newspaper articles, downloaded Internet postings, and television news report transcripts produced between 1999 and 2001. My sources included the two national television networks (CTV and $\mathrm{CBCl}$, and print and Internet archives of Canadian newspapers (The Toronto Star, The Globe and Mail, the National Post, the Vancouver Province, and the North Shore News). 
I organized my search by seeking news and editorial coverage surrounding key events in each family's story. Other news sources were consulted, but I did not add them to the analysis if they contained articles reprinted from primary news sources (e.g., news articles circulated by Canadian Press, Associated Press, Reuters).

I coded all texts by hand. A second rater reviewed the coding to evaluate its accuracy. I also presented the analysis at the Canadian Women's Studies Association conference held in Toronto, Canada in June 2002. Presenting at this conference was an opportunity to test the credibility and validity of the analysis, and to further gather public reaction to the two cases.

\section{Case Presentations}

Case One: Kimberly Van de Perre vs. Theodore Edwards

Kimberly Van de Perre was projected into the media spotlight because her former lover argued that the existence of racism in Canada and the United States necessitated that he have custody of their son. Ms. Van de Perre had given birth to a boy after an 18-month affair with a married basketball player, Theodore Edwards. Ms. Van de Perre, a white woman living in British Columbia, initially won full custody of their son, Elijah. This changed when his father, an African American man with a family in North Carolina, successfully appealed the decision and won custody. The court's widely publicized decision was influenced by arguments from Mr. Edwards, his wife Valerie Edwards, and organizations representing the black Canadian and American communities. They asserted that Elijah would be perceived as a black child and needed to be in a black family household where he could be equipped to deal with racism. They also suggested that the child's future problems with racism would be better managed if he was in the United States among other black people.

The custody battle between Kimberly Van de Perre and Theodore Edwards revolved around issues that clearly implicated race. It was difficult to argue against the assertion that their biracial son would be perceived as black. American law and policymakers have historically safeguarded white racial purity by designating the children from interracial relationships as "non-white." The discomforting reminder of a time of "one-drop" rules could not be removed by idealistic notions of such children being "an equal mixture." Media images affirmed the child's destiny. Elijah was shown to the world wearing a basketball outfit and shooting a ball at the hoop someone had erected in his mother's home. The news story defied us to look beyond the stereotypes and deny his blackness. Equally compelling were the images of his African American father and stepmother standing as a united team against the single, white woman 
from British Columbia. The British Columbia Court of Appeal concluded that Elijah needed these black parents to prepare him for a racist world. Valerie Edwards was very important in this determination. She appealed to the court to recognize the importance of her stepson being raised with his black family, but she also presented a picture of selfless, nurturing, strong black womanhood. Ms. Edwards assured the court that she was prepared to forgive her husband his indiscretions, and provide a stable family environment for his son.

The Edwards's lawyers were relying on the court's willingness to embrace a troubling stereotype. The ideal of the strong, black woman who nurtures children and forgives her philandering mate is one that has its origins in the exploitation of black women as workers and breeders during times of slavery. The internalization of this mythology to bolster the self-esteem of modern black women does not change that it is the foundation upon which these women continue to be exploited as laborers, child caregivers, wives, and mothers. The Edwards's claims of both black strength and black vulnerability were superficially empowering, but may have served to reinforce deeply embedded racist ideology. There was no commentary on how the request for segregation, and the stereotyped images used to bolster the case, helped to sustain images and ideas that denigrated black people. While the Edwards held themselves up as icons of black family values, they could not have given much thought to the consequences this would have for other black families who did not support racial separation, or did not wish to be judged against the dynamics in this marriage. They sacrificed these wider concerns in favor of legal strategy. Faced with the problematic stereotype of a hypersexualized black man violating a vulnerable white woman, the Edwards constructed a story in which Ms. Van de Perre would be viewed as dangerous and predatory. They contrasted their image of black solidarity and vulnerability against the disquieting image of a racist, promiscuous white woman. Ms. Van de Perre's whiteness cast her as a potential oppressor in this story, reinforced by Theodore Edwards's claims that she was training their child to despise black people, including his family. In the race-based drama that developed around the family, Ms. Van de Perre was presented as empowered, but she was also disadvantaged. The Edwards's legal team used her history as a white woman who had been involved romantically with a number of black professional athletes to sabotage her character. In both Canada and the United States, society has judged white women harshly for becoming involved with men who are not considered white (Backhouse 1999; Lewis Jr., Yancey, and Bletzer 1997). The Edwards's could use this stigma to strengthen their case. They presented this single woman's penchant for dating basketball players as evidence of her low moral character. In the end, Ms. Van de Perre was severely disadvantaged by the presentation of arguments formed around race. In contrast, Theodore Edwards benefited 
greatly from transplanting an American-style racial rights claim into a Canadian context that was poorly equipped to address it.

\section{Case Two: Nadia Hama vs. Kield Werbes}

Nadia Hama gained media attention almost two years before she was denied custody of her children. She became infamous due to circumstances that, at the time, seemed to have little to do with racial tensions. Ms. Hama took her son and daughter to a tourist attraction, and during the course of that visit, her 18-month-old daughter fell from a suspension bridge. Tourists at the attraction had taken pictures of Ms. Hama moments before and after her daughter's fall, therefore the media was able to project her image and the story throughout the country. The child, Kaya, survived the 40-foot drop with minor injuries. However, the coverage of her miraculous survival was quickly overshadowed by reports that the police had arrested Ms. Hama at the site, and launched a criminal investigation. The police told the media that they believed Ms. Hama had attempted to murder Kaya because she did not want to care for a child with Down's syndrome. Child welfare authorities took custody of Kaya and her 5 -year-old brother Jovan while the police conducted their investigation. In the end, the police dropped the charges against Nadia Hama because there was insufficient evidence against her. Child welfare authorities returned the children to her care, but their father sued for custody. His decision to do so superimposed a custody battle on an ongoing, very contentious, struggle for marital assets. The court eventually decided that Kjeld Werbes should have custody of the children. On the day that he arrived to remove them from her home, Nadia Hama told reporters that she was the victim of racism.

The connection between race and the custody conflict between Nadia Hama and her ex-husband was not immediately apparent. Ms. Hama's claim of racism was a late entry to the story that had begun two years earlier at the suspension bridge. The press reported her declaration that "If I was white with blue eyes, the world would come to my feet. But I am a dark woman so I have no respect in this country." Although it was clear from listening to Ms. Hama's accent that she did not speak English as her first language, it was less clear that she was a woman of color. The television clips presented an apparently white woman claiming racial disadvantage. When I discussed this with my class at the time, I presented a video of the news story. Both in the class and at the women studies conference, the groups did not know how to understand the woman's claim in the absence of unambiguous, visible, difference. I would eventually reveal that Ms. Hama was of Syrian descent, and this made it easier for people to recognize the possibility of racism in her life. Yet, I was aware that the confusion revealed the persistence of unspoken rules about the color line that divides white from non-white. Although there is growing 
awareness of race and racism in Canada, these audiences could not recognize its relevance because Ms. Hama's skin tone did not present sufficient visibility.

My investigation of the media discourse raised intriguing questions about the impact of racism on the treatment Nadia Hama had received since the accident with her daughter. For example, Kaya's fall resulted in Ms. Hama being arrested and held for 24 hours of questioning without a lawyer. Police justified their actions by referring to her display of "inappropriate" emotion when her daughter fell and citing her husband's accusatory call to the police. Although the police would later say the investigation was stimulated by computer records indicating that Ms. Hama had sought information about adoption of children with disabilities, they acknowledged that these records were revealed in subsequent investigation, and were interpreted based on the husband's allegations.

Within weeks of Kaya's fall, newspaper columnists were discussing Nadia Hama in articles that linked her alleged act to infanticide practices in "ancient" and "non-western" cultures. The media conjured the image of a savage woman committing the modern equivalent of leaving her defective child to die on a mountainside. Journalists also exoticized her presentation, reporting regularly on her emotionality, her colorful clothes, and her rich, dark hair. Even a former male friend's description of her as "an alluring, beautiful woman and a good belly dancer" was newsworthy. They juxtaposed this image against descriptions of her ex-husband, always depicted as a refined man who was "impeccably dressed" and who "rarely showed emotion." No one ever reported on his cultural background, his reaction to the birth of a child with Down's syndrome, or any opinions his friends may have offered about his character or ability to belly dance.

Reviewing the events of the past two years, one can imagine that Nadia Hama asked herself, would this happen to a white woman with blue eyes? Still, another possibility was that she was under attack because the courts and the nation saw her as a mother who had attempted to kill her disabled child. In 1994, the Canadian courts had proclaimed their lack of sympathy for homicidal parents of disabled children by sentencing a father to life in prison for killing his disabled daughter. Nadia Hama would likely have faced an equally harsh fate if the police had found any evidence that she had intended to kill her daughter Kaya. ${ }^{1}$ However, after the charges were dropped, the accident with Kaya served primarily to remind the public of Ms. Hama's past notoriety. The effectiveness of this strategy was indicated by the fact that although the Supreme Court judge acknowledged Ms. Hama was innocent of trying to harm her daughter, she noted that the event "raises serious issues as to her mental stability and the bizarre, dangerous choice of venture she made with the children as her captive participants" (Ivens 2001). The accusation that Kjeld Werbes was mobilizing against his ex-wife paralleled accusations that have historically been used 
by dominant groups to malign racialized minority groups. White people have conventionally reinforced their right to seize and socialize children of other races by disseminating myths about the propensity for adults in those populations to neglect, abuse, sacrifice, and sexually exploit their children (Bishop 2002). In the absence of evidence to substantiate any direct claim that Nadia Hama was an abusive or neglectful parent, her adversaries paraded her exotic "otherness" and unconventionality before the courts and media, allowing them to draw their own, racism-based conclusions about the risk she posed for her children. In contrast, her exhusband presented an image of Canadian whiteness that was useful for asserting his right to seize and socialize the children that had resulted from their marriage.

\section{Analysis}

Single Axis Analysis: Is Race at the Heart of These Cases?

Engagement with the idea that individuals represent multiple identities has encouraged analyses that integrate multiple categories of social difference and oppression. Still, some argue that there are some types of oppression that are analytically distinct because they are so central to the workings of power. These theorists would argue that racism merits this status because of its historical and current significance, its relevance across contexts, and its association with both everyday and apocalyptic acts of violence. For example, Sherene Razack (1999) suggests that there are times when it may be necessary to focus on racism exclusively as a site of analysis, but this does not mean that all other oppressions should be subsumed by it. These child custody cases may have merited such an analysis. The media discourse revealed issues and biases surrounding race influenced the family conflicts experienced by both Kimberly Van de Perre and Nadia Hama. Ms. Van de Perre was transformed into a powerful, dangerous, immoral woman because of her white skin and her choice of non-white sexual partners. Ms. Hama was put forward as savage, infanticidal, and unstable based on her accent and ethnic background. Both women were undermined by the overt and covert operation of racist ideology. Yet the media discourse also reveals that there are reasons why this single axis of analysis was limited.

A major limitation of the race analysis was that those individuals presenting it attached an expectation that the audience would equate status as a victim of racism to status as a disempowered, vulnerable person. When Theodore Edwards stood in front of news cameras speaking of the unique risks faced by black men in a racist society, he expected us to focus on his ex-lover's racist potential, rather than his power as a 
well-educated, extremely rich man. Similarly, Nadia Hama did not dilute her claim of victimization due to racism with details of her education, resourcefulness, and relative social privilege as the ex-wife of a securities lawyer. They used these claims of racism as a shield against scrutiny of the class privilege that would render them less sympathetic figures. As the public has become more comfortable with hearing the word "racism," and associated terms like "minority," these words have become powerful symbols. They immediately evoke images of exploitation, injustice, suffering, and lack of political power (Wilkinson 2000). The lack of precision involved in assessing claims of marginalized status has made it possible for people to make declarations that are difficult to substantiate or refute. The audience at the women's studies conference debated what we judged to be equally distasteful alternatives: refusing claims of racism (and other types of oppression) unless they are verified empirically, or accepting all claims without critical examination. The specific details of these cases prevented us from defining deontological principles that led to satisfying solutions. For Theodore Edwards, the court's solution was to acquiesce to his claim of racism and award him custody. For Nadia Hama, the court's solution was to ignore her claim of racism and deny her custody. Neither solution seemed entirely satisfying, particularly when we considered their implications for the children involved.

The effect that claims of victimization by racism had on the cases were augmented by complex dynamics surrounding whiteness. The complement to the conviction that racism is an overarching determinant of social relations is that white privilege is a pervasive and overarching determinant of power relations. Therefore, in the same way that we are expected to equate the claim of racism with victimization, we are expected to equate the accusation of whiteness with domination. Whiteness conferred on Kimberly Van de Perre the status of being a perpetrator of racist ideology until she could prove herself innocent. Whiteness also positioned her as an unsuitable parent for a biracial child. In the other case, people ignored Nadia Hama's claim of racism because she was perceived as too white to contend she had been victimized by it. Although she had several experiences that are familiar manifestations of racial discrimination, the media constructed her as a liminal figure, unable to fully claim social privilege or social exclusion. In both situations, ideologies surrounding whiteness proved just as problematic as the representations of the "other" victimized by racism. For Kimberly Van de Perre and Nadia Hama, the superficial interpretation of their family situations through the lens of racialization had powerful, destructive effects. These interpretations promoted distortions that affected the ways they were evaluated as mothers, and they distracted attention from the patterns of domination that were defacing them in the eyes of the court and the public. 


\section{Intersectionality: Multiple Identities and Multiaxial Analysis}

Broadening analysis to incorporate multiple identities can open possibilities for moving beyond the limitations of a single axis analysis. Early theoretical attempts to deal with multiple identities through additive models, pointing to multiple jeopardy and multiple advantage, oversimplified the shifting meanings given to identities under different conditions (West and Fenstermaker 1995). The collaborative relationships between systems of race, class, gender, and other oppressions needed to be addressed through multiaxial analyses (Collins 2000; Crenshaw 1991; Hooks 1995). This method gives us a way to move beyond oppositional, hierarchical divisions that often emerge from single axis analyses. Race, gender, class, and other categories of difference are ever-present determinants of experience that fuse in people's lives (Weber 2001). From this perspective, it becomes clear that the experience of racism is altered by gender, class, and other differences. When I applied this understanding to the situations of Kimberly Van de Perre and Nadia Hama, moving beyond a race analysis introduced issues associated with other, unacknowledged, aspects of their identities. Specifically, gender and class analyses both added considerations to these situations that I believed would have altered public perceptions and opened avenues for advocacy.

Ideas about gender and associated maternal and paternal roles played a large part in decisions about who was appropriate to parent the children in these families. In the public mind, the ideal female parent is highly responsible, completely selfless, and asexual or sexually pure. When the courts and the media held these women to this standard, the relationship histories of both Kimberly Van de Perre and Nadia Hama were problematic. Edwards's lawyers repeatedly described Ms. Van de Perre as a "groupie" who sought lovers in nightclubs, even after Elijah was born. Werbes's lawyers presented Ms. Hama's previous marriages and relationships as evidence of her emotional instability. Clearly, both women had stepped outside of acceptable gender role and maternal role performance. The men who were suing for custody of their children also had complex relationship histories, but these backgrounds did not carry the same consequences for them. Theodore Edwards, known to be a serial philanderer, compensated for his history through his possession of the ideal parent: his selfless, forgiving, sexually pure wife. A man is often able to improve his status in a custody case by presenting a wife who confers an image of idealized, heterosexual nuclear family functioning. Divorced men are far more likely to remarry than their ex-wives, and therefore, typically enter a custody conflict with this advantage. Although Kjeld Werbes did not have a new wife by his side, he, like many fathers, was held to a much lower parental standard than his ex-wife. His financial security and his available extended family presented a very positive picture to the court. Ms. Hama, an immigrant without biological family members 
in close proximity, and a homemaker without personal assets or secure paid employment, did not measure up nearly as well. It is revealing to see that the court awarded Mr. Werbes custody acknowledging he had little experience of parenting, but noting that he was "showing a commitment to getting to know these kids." The fact that he had not demonstrated this commitment at the time his children were placed in foster care was not a barrier to him re-inventing himself as an ideal father. Research shows that upper-class fathers with custody of their children are not likely to parent directly, but instead, purchase surrogates to provide caregiving for them (Erickson and Gecas 1991; Silverstein and Auerbach 1999). As Mr. Werbes had little personal experience of parenting, it is likely that the court viewed his capacity to purchase childcare favorably. The courts do not give women the same latitude to meet parenting needs through the purchase of services. Furthermore, it is hardly a viable alternative; the lower earning potential of most women makes paid childcare an unaffordable option (Ward, Dale, and Joshi 1996). Therefore, gender-based power relations reinforce high expectations for maternal performance, low expectations for paternal performance, and unequally distributed opportunities for securing either paid or spousal assistance with childcare. Despite assertions that men and women are now being held to equal standards for parenting (Brems, Carssow, Shook, Sturgill and Cannava 1995|, these cases suggest otherwise.

The gender issues are closely associated with class issues, since patriarchy structures financial disadvantage as well as gender-based disadvantage. In both cases, the women fighting for custody were facing men who were very wealthy. Legal battles for custody can be reduced to a flexing of socioeconomic muscle, which men are more likely to possess. Although they are able and willing to lavish resources on defeating their former partners, they are less willing to flex the muscle to provide spouse or child support. Lawyers in both custody cases tried to portray the men as victims of greedy women. The idea that these women could have had children for financial gain is one that was apparently credible enough to be circulated in the media (see for Van de Perre; for Hama). The public finds this story is credible because of an existing discourse about single mothers and their ignoble quest for financial support. Unable to hold children accountable for supporting themselves, fathers, lawyers, and the community hold mothers accountable for family breakdown and expect them to bear the financial consequences alone (Kingfisher 1999; McCarthy 2001). The group that we call single mothers includes women who experience poverty, racial discrimination, disability and other disadvantages. Yet the public and the states associate single motherhood with irresponsibility and self-indulgence (Jayakody and Stauffer 2000; Rhodes and Johnson 2000). In this context, the public denounces women for seeking child support resources from either the state or their children's fathers. Mothers 
are expected to take sole responsibility for providing for children. The community only becomes involved in the lives of the poorest families, agitating for state-sponsored surveillance and control of marginalized women and their children.

These attitudes create an environment in which fathers and the welfare state can provide meager or no support with little fear of consequences. The consequences are borne by mothers and their families. The effects of reluctant or absent child and spouse support extend beyond material disadvantage. One of the major sources of psychological distress among single mothers is financial hardship. Increased exposure to stress and low social support contribute to elevated levels of mental health problems for these women. Therefore, when Theodore Edwards and Kield Werbes elevated their positions by calling attention to evidence of emotional instability in their children's mothers, they were capitalizing on the effects of stress they had probably helped to create. For example, the Supreme Court judge said of Nadia Hama, "She strikes me as a person who is far from settled. Her career is completely undecided. Her financial situation is in chaos. Her personal life is in disarray" (Ivens 2001). The courts blamed both Ms. Hama and Ms. Van de Perre for their turbulent lives, overlooking the contributions that their children's fathers made to their individual and family dysfunction.

In a custody battle, fathers can use economic advantage to create differences in levels of stability, and create a picture of vast differences in security. These fathers exhibited their financial capital to emphasize their capacity to provide homes with superior resources. A public and court system influenced by class elitism assumes that placing a child in the custody of a poorer parent is an unfavorable outcome. They do not acknowledge that these mothers are often poorer due to gender disadvantages in the workforce, careers disrupted by disproportionate parenting responsibility, and financial stress caused by fathers and ex-husbands who feel entitled to withhold support payments. Furthermore, patriarchal capitalist assumptions that underlie family law and policy devalue the mothering these women provide, assigning it financial support designed to confine women and their families to meeting the most basic subsistence needs.

When we examine these factors together, we get a more balanced picture of the people who were involved in these cases. For example, Theodore Edwards's claims about racism need to be understood in the context of how his vulnerability was ameliorated by his status as a married, wealthy, famous American man. Because of those other identities, he had several advantages over Kimberly Van de Perre. He could present the wife that bolstered his case. He could purchase the legal power to defend his case. He could garner the attention of the press and multiple supportive advocacy organizations. He could also intimidate Canadian courts with 
the claim of black identity as an American identity, and the threat that an unfavorable decision could unleash an undesirable clash with the powerful American government. In contrast, Kimberly Van de Perre had white privilege. This may have contributed to her ability to garner media attention as well. However, she was a single woman supporting herself and her child through work as a receptionist, social assistance, and child support payments. She had no resources to assemble an idealized family, purchase powerful legal support, surround herself with advocates, or intimidate the Canadian government.

When I presented videotaped footage of the two parents, audiences in the classroom and the conference immediately commented on the power imbalance. The visual presentations of the two parents (physical size, quality of clothing, size of entourage) immediately made visible the power that this man could have over this woman. Casting her as the more powerful agent in the Edwards-Van de Perre case was a misrepresentation that was only possible by overlooking other aspects of her life. Similarly, racist ideology was used to portray Nadia Hama as an unstable, dangerous woman. She attempted to contend with this image by asserting her victimization by racism. Yet there were other important factors in her story. For example, she may have had some financial privilege as the wife of a securities lawyer, but court documents revealed that her exhusband was holding her a financial hostage. He refused to pay child and spousal support, and hid his assets to avoid accounting for them in the divorce settlement. She also compared unfavorably to her former spouse because she was an immigrant to Canada. Unlike Mr. Werbes, she could not assemble a network of Canadian relatives to bolster her image in court. Her ex-husband's presentation of her instability to the court was very successful when that instability was attributed to her exotic character/racial status. It would have been less successful if these other factors had been examined, revealing the contextual issues and prejudices that were constructing an image of instability in her life. Moving beyond a race analysis reveals that these women were both oppressed in ways that were not explored in the press, or articulated by anyone else. This distorted representation likely had implications for the decision-making in these particular custody cases, but one can imagine that it also reflected challenges that are faced by many women who enter child custody negotiations with structural disadvantages associated with their race, gender, and class status.

There are some specific gains that these women could have made based on a broader perspective of their situations. Both were isolated by the race analysis, but they could have drawn on a collective if they had been able to integrate gender and class issues into the conceptualization of their situations. These women were like many women who must enter custody and access hearings with less financial and social resources than 
their male partners. A consultation conducted by the National Association of Women in the Law confirms that Canadian women across race, class, sexuality, and citizenship divisions are hindered by existing policies that are activated in custody and access disputes (National Association of Women and the Law 1999). So it is somewhat surprising that despite the high profile of these custody cases, neither woman received any public support from women's advocacy groups.

Theodore Edwards had been able to mobilize the support of the Jamaican Canadian Association, the African Canadian Legal Clinic, and the Black Social Workers' Association to support his claims of race vulnerability. In contrast, not one women's organization stood beside Ms. Van de Perre. She reported, in fact, that 51 lawyers refused her case. Nadia Hama was also left to fight her battle alone. There is no record of either woman receiving help from any women's organization, and there is also no record in the media discourse of commentary from any group or individual attuned to the gender/class issues. There was a missed opportunity to advocate not just for these women, but for the many others who were in similar circumstances. Perhaps the media representation of these cases as contests of race-based power was so persuasive that it distracted from the gender and class issues that seem so prominent in retrospect.

Confining analysis to the single axis of race or any other identity is a foundation for the type of distortion that can result in people not receiving help they need. When we choose to make specific oppressions more salient, it is at the expense of excluding other possibilities for collective action (Briskin 1990). For these women, the saliency of race in the presentations of their situations may have prevented women's organizations from recognizing the opportunity to support them and advocate for women in similar situations. It may have also made them reluctant to intervene. These women were socially disfigured through the work of journalists, judges, lawyers, and social service organizations. Advocates in Canadian women's organizations may have evaluated Kimberly Van de Perre and Nadia Hama as inappropriate representatives of single mothers. Yet there are ways in which the individual cases could have been used to engage with the collective issues. For example, in press reports surrounding a recent rape accusation against an American basketball player, legal advocates from American women's groups have been on television discussing the wider implications of decisions that are being made about admission of evidence and acceptable lines of questioning. Similarly, Canadian or American organizations could have spoken to the all-toocommon gender and class elements of these cases. It is unclear whether they were unaware of the potential to do so, were unable to attract the attention that the black community organizations did, or were averse to intervening on the behalf of two women who had already gathered such negative media attention. ${ }^{2}$ 


\section{Conclusions and Implications}

The media portrayed these family situations through narrowed discourses that obscured the complexity of the decisions that the courts were making. Through the lens of a race-based analysis, the parents of these children could be fit into dichotomous, oppositional, hierarchical categories that created a neat façade upon which custody decisions could be made without ambiguity. This presentation reflects a tendency for the public, the media, and the courts to function most easily in situations within which villains and victims can be clearly identified. This is the appeal of a single axis analysis. We desire stories that lend themselves to straightforward dissections that can be presented in easily digestible forms. The media meets this need, serving the stripped-down details of people's lives in newspaper headlines and television sound bites. When someone broadens the axes of analysis, it challenges our belief that it is possible to make clear, certain decisions about who is in the right, and who is in the wrong. Therefore, the media, the courts, and other institutions collaborate in fitting the complex details of real life into simplified dramas. They call our attention to the most visible, and most salient aspects of the cases. They cast people into hero roles and villain roles that inevitably obscure the complex operation of power relations beneath the surface.

This analysis has addressed gender and class issues that were previously overshadowed by the race analysis, but there are other axes of analysis that could still be introduced. We could ask, for example, how xenophobia and ethnocentrism influenced a Canadian court to assert that Elijah Edwards belonged in the United States among African Americans. The court's ethnocentric belief that Canada is a white nation weakened Kimberly Van de Perre's claim that her child belonged in the country where he had been born. Theodore Edwards's rationale for removing his son from Canada suggests nationalist sentiments, but also evoked images of imperialism; the American conqueror asserted his ownership of the property he had acquired in another nation. Gender-based power relations intersected with ethnocentrism and national power relations to promote different outcomes for these parents. The addition of more axes of analysis furthers our understanding of the oppression experienced by Ms. Van de Perre and the power held by Mr. Edwards. Similarly, we can consider how ableism, and prevailing ideology surrounding the burden of living with a disabled child, could have influenced the custody decision for Nadia Hama. Although her commitment to raising Kaya was questioned, her husband's willingness to take custody of the child bolstered his image. The media suggested she was an unscrupulous mother because she was parenting in a situation she may have appraised as burdensome. In contrast, they promoted the idea that her ex-husband was an exemplary father 
because he was willing to parent in a situation that he may have appraised as burdensome. Gender role expectations intersected with ableism to promote very different perceptions of these parents. Again, we are made more aware of the multiple oppressions experienced by Ms. Hama, and the power held by Mr. Werbes. The specific axis through which a situation is represented (whether constructed by the media, lawyers, social service agencies, advocates, or the individual) can only be viewed as an isolated segment of a person's situation. People's lives are understood more fully when we approach them based on knowledge of multiple identities and a variety of relations to oppression and privilege. Yet, as the axes of analyses grow, the complexities of situations increase. It points us toward the realization that naming oppression and naming privilege is not enough to promote social justice.

We need to develop frameworks that allow us to move beyond recognizing the presence of oppression and privilege. It is more helpful to be able to evaluate multiple identities in terms of their consequences in people's lives, and their potential as the foundation of anti-oppressive strategies. Kimberly Van de Perre and Nadia Hama could do little within an analysis that penalized them for their racial categorizations, but a more integrated analysis would have pointed to the consequences that class, gender, nationality, and other identities had in their lives. For example, advocacy calling attention to the construction of economic disadvantage for single mothers could have provided a context for addressing the material advantage that was being used to position them as inferior parents. Similarly, attention to the gender power issues could have promoted examination of the disproportionate distribution of childcare responsibilities and its implications for attaining education, employment, and broad-based social support. An analysis based on the citizenship issues could have raised important questions about the diminished status that immigrants face in conflicts with individuals who are permanent citizens, and the disadvantage that a Canadian faces in taking on a influential American. These identities had implications for presenting the personal and social resources that the court was using to measure adequacy to parent. However, these identities also could have provided opportunities for seeking additional support and forming a basis for advocacy. These women could have received help if they had connected with other women, other single mothers, others with immigrant or non-citizen status, or others whose identities represented intersections of these statuses. As individuals, they could have benefited from counseling or legal consultation that would have diminished their isolation and helped them develop an understanding of their individual troubles as part of broader social problems. This would have been an important counternarrative to the legal and social discourse their former partners were using to position them as problem mothers. These women needed to be linked to networks and resources that could provide social 
support and concrete assistance with their custody battles. Expanding their networks of supportive relationships could have involved them in collective activity that would have been instrumental in challenging the policies that encumbered them as women and mothers. These are all interventions that are part of a repertoire of feminist responses to the oppression that women face in multiple venues (Deitz 2000). As feminism is increasingly engaging with the issues faced by women who face oppression from multiple identity locations, intersectional analyses are an important tool for developing multiaxial strategies for advocacy.

An examination of intersectionality helps us understand augmented experiences of oppression, but also identifies unique opportunities to make use of privilege (Browne and Misra 2003). It is most possible to benefit from available networks and resources to fight oppression when an individual or group is also able to make use of privileged statuses. Theodore Edwards's mobilization of legal and social support to launch his race-based claim is an excellent demonstration that the capacity to address oppression is influenced by the access that one has to positions of privilege. Similarly, the women in these situations had privileges that likely contributed to their ability to deal with the oppressions they were facing. Kimberly Van de Perre's status as a white woman likely attracted media attention that would not have gone to a black woman in the same situation. Although she lost that stage of the custody battle, the level of attention that the case received would ensure that the courts could not dismiss her easily in the future. Similarly, Nadia Hama's middle-class status, education, and resourcefulness made her more able to navigate her divorce and custody proceedings than many other women. She used these assets to withstand the difficulties she had encountered already, and they would probably aid her in the future. Although oppressive power relations multiply disadvantaged both women, they also had some privileges that could be used to help them deal with the consequences. We need to understand the operation of both oppression and privilege in peoples' lives in order to construct appropriate strategies for advocacy. Recognition of privilege can point to resources that individuals have to advocate for themselves, but it can also point to resources that people within a group have to advocate for the collective. If we allow ourselves to be confined to single axis analyses that freeze individuals in positions of being empowered or disempowered, we risk missing important opportunities to advance social justice. Resisting the ease of single axis analysis is important in any context where we recognize the multiple dimensions of identity in individuals' lives, and the multiple ways in which they can choose to identify or be identified by others.

As we look forward to the future, we need to think about what will make us critical consumers of information we receive through media, but also through case reports, medical records, and other texts that document 
people's lives. Our analyses need to facilitate recognition of how distorted representations can perpetuate social injustice and how multidimensional representations can create possibilities for fighting social injustice. As this analysis demonstrates, the failure to be integrated in our approach to people and their problems leads to superficial interpretations that can be deleterious to their welfare and can overlook the potential for empowerment in their lives. Although there will be reasons to preserve sites for engaging with specific types of oppression, we must also develop analytic skills to guide us in addressing the reality that oppression and privilege operate simultaneously in people's lives.

Charmaine C. Williams is on the Faculty of Social Work, University of Toronto. She may be reached at 246 Bloor Street West, Toronto, On M5S 1A1; Phone: 416-946-8225; Fax: 416-978-7072; E-mail: charmaine. williams@utoronto.ca.

\section{Notes}

1. Some readers may wonder if this analysis overestimates the impact of racism in undermining Ms. Hama, while underestimating the impact of the alleged infanticide. I have started the analysis with a focus on the impact of racism because Nadia Hama suggested this analysis; however, I also believe there is compelling evidence for her position. There are some interesting differences in the experience that she had as a parent accused of attempting to murder her child, and the experience of Robert Latimer, the man who was convicted of murdering his daughter. Latimer, a white man, ended his disabled 12-yearold daughter's life by carrying her to his truck, and rigging a hose to fill the cabin with carbon monoxide. He stood in the house and watched his daughter, Tracy, die. Some journalists reporting on the story aided Latimer in presenting himself as a loving, overburdened father, who committed a suicide for the daughter who was too disabled to do it herself. Other journalists urged the public to see him as the murderer of a helpless child with a worthwhile life. In contrast, the media was unanimous in presenting Nadia Hama as a woman capable of murder, some basing this assertion on a vague link to primeval, non-Western culture. There is an important difference here. The public was asked to see Robert Latimer as either a merciful or malevolent individual, while viewing Nadia Hama as the representative of an exotic, bloodthirsty outsider group. What we see is that white privilege confers the freedom to be evaluated as an individual, while racial minority status confers the burden of having unacceptable acts attributed to the negative attributes of an entire race.

2. The only women's organization that presented a public response to either of these cases was the Ontario Women's Justice Network /cited in this paper as Cross 2001). Their Web site contains a post-hoc analysis of the Van de Perre/ 
Edwards decision, discussing its implications for positioning race in child custody cases. An organization that could potentially have involved itself was the National Action Committee on the Status of Women (NAC), an umbrella organization that includes more than 700 member groups located across Canada. I reviewed their web site for evidence of response to these cases from NAC or a NAC member group, but found none. NAC's current focus appears to be national and international labor and immigration policies. Perhaps the lack of involvement reflects shifting priorities in Canadian feminist activism or insufficient resources to address these high-level policy issues and also respond to situations like the ones described in this paper. The National Association of Women and the Law (NAWL) is involved in advocating around custody and access issues, but their online and print documents do not refer to these cases or any specific family situation. The unavailability of a public record of internal discussion of these cases does not mean that they were not discussed. They may have been highly relevant to work that both organizations were doing in the areas of national and international policy. Women's organizations may not have stepped forward to offer support or analysis in these cases, but I believe that the silence of women's organizations must be understood as an interaction. The media did not seek out their perspectives as they did seek expert commentary on racial issues for the Van de Perre case. Apparently, reporters believed that expert interpretation was necessary to contextualize the race issues, but they did not believe that expert interpretation was required to contextualize the gender issues.

\section{References}

Austin, I., and Panton, V. 2000. "Blue wins custody of love child." The Vancouver Province, March 10. Retrieved on December 30, 2001, from http://www. vancouverprovince.com/grizzlies/stories/000310/3733027.html.

Aylward, C. A. 1999. Canadian critical race theory: Racism and the law. Halifax: Fernwood Publishing.

Ayre, P. 2001. "Child protection and the media: Lessons from the last three decades." British Journal of Social Work, 31, 887-901.

Backhouse, C. 1999. Colour-Coded: A Legal History of Racism in Canada, 1900-1950. Toronto: University of Toronto Press.

Bailey, I. 2001. "Father takes custody of children from Hama: 'You're coming with me'-Vancouver mother dropped baby off suspension bridgc." The National Post, June 18, pp. A1, A4.

Bishop, A. 2002. Becoming an ally: Breaking the cycle of oppression in people. Second edition. Halifax: Fernwood Publishing.

Blommaert, J., and Bulcaen, C. 2000. "Critical discourse analysis." Annual Review of Anthropology, 29, 447-66.

Boyd, S. B. 1996. "Is there an ideology of motherhood in (post) modern child custody law?" Social \& Legal Studies, 5(4), 495-7.

Brems, C., Carssow, K. L., Shook, C., Sturgill, S., and Cannava, P. 1995. "Assessment of Fairness in Child-Custody Decisions." Child Abuse \& Neglect, 19(3), $345-53$. 
Breton, R., Isajiw, W. W., Kalbach, W. E., and Reitz, J. G. 1990. "Introduction \& Conclusion." In R. Breton, W. W. Isajiw, W. E. Kalbach, and J. G. Reitz, editors, Ethnic Identity and Equality: Varieties of Experience in a Canadian Society (pp. 3-13). Toronto: University of Toronto Press.

Briskin, L. 1990. "Identity politics and the hierarchy of oppression." Feminist Review, 35, 102-8.

Browne, I., and Misra, J. 2003. "The intersection of gender and race in the labor market." Annual Review of Sociology, 29, 487-513.

Cairney, J., Boyle, M., Offord, D. R., and Racine, Y. 2003. "Stress, social support and depression in single and married mothers." Social Psychiatry and Psychiatric Epidemiology, 38(8), 442-9.

CBC News Online staff. 1999. "Mother of bridge baby accuses RCMP of unfair treatment." $C B C$ News Online, September 30. Retrieved on December 30, 2001, from http://cbc.ca/cgi-bin/templates/view.cgi?/news/1999/09/30/ babyfalle90930.

Chang, G. 2001. "B.C. mom who lost tot off bridge, loses custody." CTV News-Canada $A M$, June 18.

Chesler, P. 1991. "Mothers on Trial-the Custodial Vulnerability of Women." Feminism \& Psychology, 1(3), 409-25.

Collins, P. H. 2000. Black feminist thought: Knowledge, consciousness, and the politics of empowerment. New York: Routledge.

Coltrane, S. 2001. "Marketing the marriage 'solution': Misplaced simplicity in the politics of fatherhood"-2001 presidential address to the Pacific Sociological Association. Sociological Perspectives, 44(4), 387-418.

Court of Appeal for British Columbia. 2000. Hama v. Werbes, 2000 BCCA 367 , Docket: CA026302. Vancouver, British Columbia: Court of Appeal for British Columbia.

Crenshaw, K. W. 1991. "Mapping the margins: Intersectionality, identity politics, and violence against women of color." Stanford Law Review, 43(6), 1241-99.

Cross, P. 2001. Important Supreme Court Custody Decision Handed Down. Toronto, ON: Ontario Women's Justice Network. Retrieved on December 30, 2001, from http://www.owjn.org/issues/custody/vandeper.htm.

Dei, G. J. S. 1996. Anti-Racism education: Theory and practice. Halifax: Fernwood Publishing.

Deitz, C. A. 2000. "Responding to oppression and abuse: A feminist challenge to clinical social work." Affilia, 15(3), 369-89.

Erickson, R. J., and Gecas, V. 1991. "Social class and fatherhood." In F. W. Bozett and S. M. H. Hanson, editors, Focus on Men: Fatherhood and Families in Cultural Context (Vol. 6, pp. 114-37). New York: Springer.

Falzon, C. 1998. Foucault and social dialogue. London: Routledge.

Henry, F., and Ginzberg, E. 1985. Who Gets the Work? A Test of Racial Discrimination in Employment. Toronto: The Urban Alliance on Race Relations and the Social Planning Council of Metropolitan Toronto.

Henry, F., and Tator, C. 1999. "State policy and practices as racialized discourse: Multiculturalism, the Charter, and employment equity." In P. S. Li (Ed.), Race and Ethnic Relations in Canada (Second ed., pp. 88-115). Toronto: Oxford University Press.

Henry, F., Tator, C., Mattis, W., and Rees, T. 1994. The Colour of Democracy: Racism in Canadian Society. Toronto: Harcourt Brace. 
Heuveline, P., Timberlake, J. M., and Furstenberg, F. F. 2003. "Shifting childrearing to single mothers: Results from 17 western countries." Population and Development Review, 29(1), 47-71.

Hill, L. 2001. Colour has to count. Retrieved on May 19, 2002, from http://www. lawrencehill.com/colourcounts.html.

Hoffman, C. D., and Moon, M. 2000. "Mothers' and fathers' gender-role characteristics: The assignment of postdivorce child care and custody." Sex Roles, 42(9-10), 917-24.

Hooks, B. 1995. Killing Rage: Ending Racism. New York: Henry Holt and Company.

Hope, S., Power, C., and Rodgers, B. 1999. "Does financial hardship account for elevated psychological distress in lone mothers?" Social Science and Medicine, 49(12), 1637-49.

Hume, M. 2000. "His 'rock' of a wife swayed the judges: Court awards custody to basketball player because mixed-race child will always be perceived as black." The National Post, March 10. Retrieved on December 30, 2001, from http://www.fact.on.ca/news/news0003/np00031b.htm.

Hume, M., and Huebner, T. 1999. "Police suspect mother threw baby off bridge: Court documents allege woman didn't want disabled child." The National Post, September 29. Retrieved on December 30, 2001, from http://fact.on.ca/ newpaper/np990929.htm.

Hume, M., Huebner, T., and Hall, N. 2001. "A woman capable of anything: B.c. mother in court: Parents of child who fell from bridge fight over custody, assets." The National Post, March 19. Retrieved on December 30, 2001, from nationalpost.com/home/story.html? $\mathrm{f}=/$ stories/20010319/504706.html.

Ivens, A. 2001. "Judge questions mother's mental stability." The Province, June 17. Retrieved on December 30, 2001, from www.canada.com/vancouver/the province.

Jayakody, R., and Stauffer, D. 2000. "Mental health problems among single mothers: Implications for work and welfare reform." Journal of Social Issues, 56|4|, 617-34.

Kingfisher, C. P. 1999. "Rhetoric of (female) savagery: Welfare reform in the United States and Aotearoa/New Zealand." NWSA Journal, 11(1), 1-20.

Kitzinger, J. 1996. "Media representations of sexual abuse risks." Child Abuse Review, 5(5), 319-33.

Lewis Jr., R., Yancey, G., and Bletzer, S. S. 1997. "Racial and nonracial factors that influence spouse choice in black/white marriages." Journal of Black Studies, 28(1), 60-78.

MacCharles, T. 2001. "Ex-NBA player accuses 'racist' lover." The Toronto Star, June 15.

Mackin, B. 1999. "Mother of baby dropped off bridge 'a loving parent'." North Shore News, October 11. Retrieved on December 30, 2001, from http://www. nsnews.com/issues99/w101199/10069902.html.

Makin, K., and Mickleburgh, R. 2001. "Ex-Grizzlie loses custody: son will stay in B.C., race should never have been an issue, Supreme Court says." The Globe and Mail, September 29, pp. A11.

Malbon, J. 2001. "High court ponders race in child custody case." CTV NewsCanada $A M$, June 14. 
Mason, M. A., and Quirk, A. 1997. "Are mothers losing custody? Read my lips: Trends in judicial decision-making in custody disputes-1920, 1960, 1990, and 1995." Family Law Quarterly, 31(2), 215-36.

Matas, R. 2001. "Mother of 'miracle' baby loses custody." The Globe and Mail, June 15. Retrieved from www.globeandmail.com.

Mayson, M. 1999. "Ontario works and single mothers: Redefining 'deservedness and the social contract'." Journal of Canadian Studies-Revue D Etudes Canadiennes, 34(2), 89-109.

McCarthy, I. C. 2001. "Fifth province re-versings: The social construction of women lone parents' inequality and poverty." Journal of Family Therapy, 23, $253-77$.

Morgan, J. 1999. When Chickenheads Come Home to Roost: My Life as a Hip-Hop Feminist. New York: Simon and Schuster.

National Association of Women and the Law. 1999. Women speak out on custody and access: Report of NAWL's on-line consultation on custody and access. Retrieved October 20, 2003, from http://www.nawl.ca/custaccess.htm.

Neal, S. 1998. "Embodying Black madness, embodying White femininity: Populist (re)presentations and public policy-The case of Christopher Clunis and Jayne Zito." Sociological Research Online, 3(4), http://www.socresonline.org. uk/socresonline/3/4/6.html.

Razack, S. H. 1999. Looking white people in the eye: Gender, race, and culture in courtrooms and classrooms. Toronto: University of Toronto Press.

Reitz, J. G., and Breton, R. 1994. The Illusion of Difference: Realities of Ethnicity in Canada and the United States. Toronto: C.D. Howe Institute.

Rhodes, R., and Johnson, M. M. 2000. "Students' perceptions of single parents and social injustice: A women's issue." Affilia, 15(3), 434-46.

Rosen, D., Spencer, M. S., Tolman, R. M., Williams, D. R., and Jackson, J. S. 2003. "Psychiatric disorders and substance dependence among unmarried lowincome mothers." Health \& Social Work, 28(2), 157-65.

Schwandt, T. A. 1997. Qualitative inquiry: A dictionary of terms. Thousand Oaks: Sage Publications.

Silverstein, L. B., and Auerbach, C. F. 1999. "Deconstructing the essential father." American Psychologist, 54(6), 397-407.

Taylor, R. L. 1997. "The changing meaning of race in the social sciences: Implications for social work practice." Smith College Studies in Social Work, 6(3), 277-98.

Van Dijk, T. A. 1993. "Analyzing racism through discourse analysis: Some methodological reflections." In I. H. Stanfield II and R. M. Dennis, editors, Race and Ethnicity in Research Methods (pp. 92-134). Newbury Park: Sage Publications.

Wallace, M. 1979. Black Macho and the Myth of the Superwoman. New York: Dial Press.

Ward, C., Dale, A., and Joshi, H. 1996. "Combining employment with childcare: An escape from dependence?" lournal of Social Policy, 25(2), 223-47.

Weber, L. 2001. Understanding race, class, gender and sexuality: A conceptual framework. Boston: McGraw-Hill.

West, C., and Fenstermaker, S. 1995. "Doing difference." Gender \& Society, 9(1), $8-37$. 
White, J. 1999. "Don't suffer the little children: Our society appears undecided on the ethics of infanticide." The National Post, December 30. Retricved on December 30, 2001, from http://fact.on.ca/news/news9912/np991230.htm.

Wilkinson, D. 2000. "Rethinking the concept of 'minority': A task for social scientists and practitioners." Journal of Sociology and Social Welfare, 27(1), $115-32$. 